\title{
The Early Sealers in West Antarctica*
}

$\mathrm{P}^{\mathrm{n}}$ ROF. W. M. HOBBS has written a long and elaborately illustrated monograph on the history of the Graham Land area of Antarctica from Smith's discovery of the South Shetlands in 1819 to Ellsworth's flight in 1936. The earlier years of this history have been much discussed by Mill, Balch, Nordenskjöld, Bruce and others, but assiduous search from time to time reveals new material, chiefly in the form of forgotten log books. Prof. Hobbs's reproductions of early maps alone give his monograph great interest. Some of his conclusions, however, do not appear to be justified from the available facts. Thus he goes to great pains to prove that the Antarctic continent was first sighted in November 1820, when the American sealer, N. B. Palmer, saw land to the south and south-east of Deception Island of the South Shetlands. This land soon after appeared on maps as Palmer Land and is now regarded as a part of the Trinity Peninsula of Graham Land. Prof. Hobbs, however, is entirely unconvincing in his refutation of the accounts and charts which are available establishing Bransfield's sighting of Trinity Land in January and February 1820. W. S. Bruce, and later R. T. Gould, have shown convincingly that Trinity Land was the original discovery of Antarctic land and preceded Palmer's discovery by at least ten months. The attempt to establish an American discovery of Antarctica fails.

The chief interest, however, in Prof. Hobbs's monograph lies in his strictures on Weddell. These strictures have a weak foundation, but since they impugn the veracity and reputation of a notable explorer, cannot be overlooked. Between 1819 and 1824, Weddell made three southern voyages in the course of which he surveyed in part the South Shetlands and the South Orkneys and gained a high southern latitude in lat. $74^{\circ} 15^{\prime} \mathrm{S}$., long. $34^{\circ} 16^{\prime} 45^{\prime \prime} \mathrm{W}$. in the Sea of George the Fourth, which is now called the Weddell Sea. He published his account of these voyages, his discoveries and his route chart in his well-known volume "A Voyage Towards the South Pole", etc. (London, 1825). He sailed southwards into the Weddell Sea about long. $30^{\circ} \mathrm{W}$. and came

* The Discoveries of Antarctica within the American Sector, as re vealed by Maps and Documents. By W. M. Hobbs. Trans. Amer. Phil. Soc., Philadelphia. New Series, 31, Pt. 1, pp. 1-71; 1939. north again between long. $30^{\circ}$ and $40^{\circ} \mathrm{W}$. from his southern record where he saw a sea frey from field ice with only four icebergs in sight. He had, however, "seen "many ice islands" in places on the way south. Ross, twenty years later, failed on account of ice to follow Weddell's route, and the Scotia in 1903 had to keep farther eastward to gain a high latitude, but in 1904 crossed the middle of an almost ice-free Weddell Sea and reached lat. $72^{\circ} \mathrm{S}$. before difficulty began. The Deutschland and the Endurance in later years were eaught and drifted in Weddell's longitudes. But from these scanty records we are not entitled to assert, as Hobbs does, that the Weddell Sea is unnavigable. The pack of the Weddell Sea is partly due to local formation in that sea and partly due to the sweep of pack from the east which is caught in this great bight. The pack is carried towards the south-west coast which may be always blocked, and then flows north before wind and current until, in the latitudes of $65^{\circ}$ to $60^{\circ} \mathrm{S}$., it is swept eastward again by the set of winds and the eastward drift of the waters. With the amount and distribution of the pack in the Weddell Sea dependent on many factors, local and general, it would be surprising if the distribution of ice remained constant, as indeed a limited knowledge of that sea shows not to be the case.

Wordie has commented on the low average wind velocity in the Weddell Sea as promoting ice congestion in the western side. A year of unusually strong southerly winds in this area might easily clear away the ice for several weeks or even for a whole season. Years or periods of open water are likely to occur, and Weddell was fortunate enough to sail in such a season. Hobbs's deductions on the state of ice, based on the scanty data available, are not a foundation for the destruction of Weddell's reputation and the slandering of his name. Similarly, Hobbs's charge that Weddell did not make surveys in the South Shetlands but merely copied Powell's earlier map (published in 1922) would seem to ignore Weddell's practice of surveying from boats and not direct from his ship, for which reason Weddell did not mark his route among island groups. It is a pity that such charges should disfigure a work that comprises much research, even if some of it lacks scholarship.
R. N. R. B.

\section{Absorption Spectra of Single Crystals of Hæmoglobin in Polarized Light}

\author{
By M. F. Perutz, Cavendish Laboratory and Molteno Institute, Cambridge
}

\begin{abstract}
CINGLE crystals of hæmoglobin generally show $S$ strong pleochroism ${ }^{1}$. They are dark red and almost opaque in two extinction directions and become light red and transparent in the third. An investigation of the absorption spectra corresponding to the principal vibration directions was undertaken with the view of obtaining information on the molecular structure of hæmoglobin.
\end{abstract}

Horse methomoglobin crystallizes in the monoclinic system, as described in a previous paper ${ }^{2}$, and is usually obtained in the prismatic form terminated by domatic faces (Fig. 1). The orientation of the optic axes may be seen from the figure; the sign of the double refraction is probably negative. The crystals show strong absorption in vibration directions parallel to $\beta$ and $\gamma$, and weak absorption parallel to $\alpha$. 